\title{
Údržba v Průmyslu 4.0 dnes
}

\author{
David Ženíšek ${ }^{1}$, Michal Šimon ${ }^{1}$, Josef Basl ${ }^{1}$, Peter Poor ${ }^{1}$ \\ ${ }_{1}$ Západočeská univerzita v Plzni, Fakulta strojní, Katedra průmyslového inženýrství a \\ managementu \\ Univerzitní 8, 306 14, Plzeň, Česká republika \\ zenisek@kpv.zcu.cz \\ simon@kpv.zcu.cz \\ basl@kpv.zcu.cz \\ poor@kpv.zcu.cz
}

\begin{abstract}
Anotace: Tento článek se zabývá analýzou současného stavu údržby ve vztahu k Průmyslu 4.0. Článek nejprve představí historický vývoj údržby ve vztahu k průmyslovým revolucím a následně interpretuje výsledky dotazníku zabývajícího se mírou využití prvků Průmyslu 4.0 v údržbě podniků.
\end{abstract}

\section{1 Úvod}

Každá průmyslová revoluce způsobuje změny po technologické, socioekonomické a kulturní stránce. Mezi technologické stránky pak patří mimo jiné i řízení údržby. Přístup k údržbě strojového vybavení se během revolucí velmi změnil; od reaktivního rízení směrem k predikci poruch. Namísto opravování poruch se dnes podniky snaží o minimalizaci rizik a nákladủ s tím spojených.

$\checkmark$ první části tohoto článku $s$ pomocí průzkumu literatury sumarizujeme charakteristiky čtyř průmyslových revolucí a vývoje řízení údržby. Podíváme se na vztah první průmyslové revoluce a reaktivní údržby, druhé průmyslové revoluce a preventivní údržby, třetí průmyslové revoluce a proaktivní údržby a čtvrté průmyslové revoluce a prediktivní údržby.

$\checkmark$ druhé části budou interpretovány výsledky dotazníku zabývajícího se mírou využití prvků Průmyslu 4.0 v údržbě podniků.

\section{2 Údržba a průmyslové revoluce}

Termín průmyslová revoluce byl prvně popularizován anglickým ekonomickým historikem Arnoldem Toynbeem a definován jako poměrně náhlá a radikální změna, která zahajuje industrializovanou společnost $v$ bytí a transformuje tuto společnost způsobem, jakým to žádná z dřivějších takzvaných průmyslových revolucí nikdy neudělala. [1]

Výrobní zařízení byla vždy postihována poruchami $v$ důsledku opotřebení a vyžadovala údržbu. S pokročilejšími stroji rostly samožrejmě také požadavky na údržbu. Švédský standard SS-EN 13306 charakterizuje údržbu jako kombinaci všech technických, administrativních a manažerských úkonů během 
životního cyklu stroje, jichž úkolem je udržování v chodu či návrat do provozuschopného stavu, za kterého může stroj fungovat. [2] První zmínky o údržbě Ize vysledovat již ve starověkém Egyptě, 600 let před Kristem [3].

\subsection{První průmyslová revoluce}

První průmyslová revoluce odstartovala $v$ Anglii a byla charakterizována změnou používání energetických zdrojů, dopravy, transferu informací a industrializací výroby. Před a během tohoto období byla nejčastějším způsobem údržby údržba po poruše, která, jak název napovídá, řeší problém (poruchu), teprve poté, co nastane. Cílem je uvést stroj do provozuschopného stavu. Tento prístup má své pro a proti a je využíván i dnes. Výhodou je, že údržba samotná je prakticky nulová, řeší se pouze opravy. Nevýhodou naopak je, že tento přístup vede ke kratší životnosti strojů a jejich nedostupnost $\checkmark$ důsledku poruch může vést ke ztrátám. [4]

\subsection{Druhá průmyslová revoluce}

Druhá průmyslová revoluce začala kolem roku 1870 a je spojena s elektrifikací a montážní linkou. Výsledkem byla hromadná výroba založená na dělbě práce a elektrifikací výrobních linek. Tato revoluce je také někdy nazývána revolucí technických věd [5], jelikož věda $v$ této době začala být spojována s průmyslem. $\mathrm{S}$ vrcholem druhé průmyslové revoluce byly stroje více složité a klíčové pro produkci. Poruchy způsobovaly vyšší náklady než předtím, a proto se podniky začaly uchylovat k preventivní, někdy také nazývané plánované údržbě. Preventivní údržba je činnost založená na konkrétním harmonogramu, který identifikuje, zabraňuje nebo zmírňuje rozklad komponent tak, aby byla zachována jeho provozuschopnost a prodloužena jeho životnost. Plánovaná údržba přináší nižší šanci na vznik prostoje $v$ důsledku poruchy, vede však k plánovaným prostojům. Již Henry Ford u svého modelu T ve FORD MANUAL [6] z roku 1919 doporučoval: "Pravidelně kontrolujte pojezdové ústrojí. Ujistěte se, že na předních nebo zadních kolech neexistuje žádná zbytečná vůle a že všechny šrouby a matice jsou utaženy. Proved'te péči o každou opravu nebo úpravu, jakmile se zjistí její nezbytnost. Tato pozornost vyžaduje jen málo času a může zabránit zpoždění nebo možné nehodě na silnici. “

\subsection{Třetí průmyslová revoluce}

Třetí průmyslová revoluce je připisována konci druhé světové války a trvá pouze do osmdesátých let dvacátého století. Je spojována s automatizací, elektronikou a rozmachem informačních technologií. Význačným je zde vznik prvního programovatelného logického automatu neboli PLC, malého průmyslového počítače. [7] $\mathrm{V}$ této době také začal vznikat nový směr v údržbě, a to sice údržba proaktivní, jež kombinuje údržbu po poruše s preventivní údržbou za pomoci analytického, daty řízeného přístupu, jehož cílem je zvýšení ekonomické efektivnosti produkce, zvýšení životnosti strojủ a snížení prostojů. Již $v$ této době se začali využívat sensory a $v$ údržbě se vedle technikư začali objevovat také IT specialisté. Dva nejznámější směry proaktivní údržby jsou 
Totálně produktivní údržba (TPM) a Údržba zaměřená na bezporuchovost (RCM). TPM je souborem nástrojů a postupů, a jejím cílem je částečné předání odpovědnosti za provoz strojů operátorům a dosažení tří nul - nulových prostojů, nulových chyb a nulových ztrát rychlosti strojů. RCM je metoda pro zavedení programu preventivní údržby, který umožní účelně a účinně dosáhnout požadované úrovně bezpečnosti a pohotovosti výrobního zařizení, a je určena $\mathrm{k}$ tomu, aby vedla ke zlepšení celkové bezpečnosti, pohotovosti a hospodárnosti provozu. [8]

\section{4 Čtvrtá průmyslová revoluce}

Čtvrtá průmyslová revoluce, která se děje ještě dnes, je charakterizována masivním rozšířením internetu a jeho průnikem do všech oblastí lidské činnosti. Hlavními prvky v průmyslu jsou internet věcí, cloud, big data, umělá inteligence, kyber-fyizické systémy, virtuální dvojčata, 3D tiskárny a další. S tímto rozsáhlým pokrokem vznikla myšlenka prediktivní údržby, někdy také nazývané Údržba 4.0, jež zapojuje tyto nové prvky a zabraňuje poruchám pomocí analýz produkčních dat (jak interních, tak externích) za účelem vyhledání vzorců, predikce poruch před jejich vznikem a nastavení vhodných akcí. Zahrnuje neustále živé sledování (real-time monitoring) v kombinaci s externími daty a optimalizuje údržbový plán. Hlavní roli zde již nehrají údržbáři, ale datoví specialisté a spolehlivostní inženýři.

V matici níže jsou shrnuty charakteristiky průmyslových revolucí a s nimi korelujících druhů rízení údržby.

Tabulka 1 - Řizení údržby v kontextu průmyslových revolucí

\begin{tabular}{|c|c|c|c|c|}
\hline $\begin{array}{l}\text { Průmyslová } \\
\text { revoluce }\end{array}$ & Průmysl 1.0 & Průmysl 2.0 & Průmysl 3.0 & Průmysl 4.0 \\
\hline $\begin{array}{l}\text { Charakteristiky } \\
\text { revoluce }\end{array}$ & $\begin{array}{l}\text { Mechanizace } \\
\text { parní stroj }\end{array}$ & $\begin{array}{c}\text { Hromadná } \\
\text { výroba, montážní } \\
\text { linka, elektrifikace }\end{array}$ & $\begin{array}{l}\text { Automatizace, } \\
\text { počítače, } \\
\text { elektronika }\end{array}$ & $\begin{array}{l}\text { Internet věcí, } \\
\text { cloud, big data, } \\
\text { uměl inteligence, } \\
\text { kyber-fyizické } \\
\text { systémy, virtuální } \\
\text { dvojčata, 3D } \\
\text { tiskárny }\end{array}$ \\
\hline Druh údržby & $\begin{array}{l}\text { Údržba po } \\
\text { poruše }\end{array}$ & $\begin{array}{l}\text { Preventivní } \\
\text { údržba }\end{array}$ & $\begin{array}{l}\text { Proaktivní } \\
\text { údržba }\end{array}$ & $\begin{array}{l}\text { Prediktivní } \\
\text { údržba }\end{array}$ \\
\hline Inspekce & Visuální inspekce & $\begin{array}{l}\text { Inspekce pomocí } \\
\text { přístrojů }\end{array}$ & $\begin{array}{l}\text { Monitorování } \\
\text { sensory }\end{array}$ & $\begin{array}{l}\text { Prediktivní } \\
\text { analýzy }\end{array}$ \\
\hline $\begin{array}{c}\text { Celková } \\
\text { efektivnost } \\
\text { zařízení (OEE) }\end{array}$ & $<50 \%$ & $50-75 \%$ & $75-90 \%$ & $>90 \%$ \\
\hline $\begin{array}{l}\text { Zaměstnanci } \\
\text { údržby }\end{array}$ & $\begin{array}{l}\text { Trénovaní } \\
\text { údržbáŕi }\end{array}$ & Inspektoři údržby & $\begin{array}{l}\text { Spolehlivostní } \\
\text { inženýři, IT } \\
\text { specialisté }\end{array}$ & Datoví specialisté \\
\hline
\end{tabular}




\section{Dotazník míry využití prvků průmyslu 4.0 v údržbě}

Během dubna 2019 byl rozeslán dotazník zabývající se mírou využití prvků průmyslu 4.0 zástupcům podniků v České republice. Obratem byly získány odpovědi ze třinácti podniků z pozic technických ředitelů, ředitelů divizí a jednatelů. Pro účely tohoto dotazníku byly interpretovány pouze odpovědi jedenácti respondentů, kteří uvedli, že jsou středními a většími podniky, jež mají 140 a více zaměstnanců, a zároveň se zabývají výrobou či výzkumem.

V dotazníku bylo položeno 49 otázek, rozdělených do sekcí: informace o podniku, podnik a Průmysl 4.0, údržba v podniku a Průmysl 4.0 v údržbě. V tomto článku se zaměříme na otázky vztahující se k tabulce „Řízení údržby v kontextu Průmyslu 4.0”. Postupně se podíváme na odpovědi pěti otázek:

1. Jaké prvky Průmyslu 4.0 využíváte v údržbě?

2. Kolik procent Vašich zařizení je připojeno $k$ internetu a je monitorováno?

3. Jakým způsobem jsou vaše zařízení monitorována?

4. Jaká je celková efektivita zařizení (OEE) na vašich klíčových zařízeních?

5. Jaké specialisty $v$ údržbářském týmu zaměstnáváte?

Odpovědi by nám měli dopomoct určit, zda čtvrtá průmyslová revoluce již dohnala údržbu v podnicích.

\subsection{Prvky Průmyslu 4.0 využívané v údržbě}

Následující otázka měla za úkol zjistit, jak hojně jsou využívány mezi podniky prvky Průmyslu 4.0 a do jaké míry jsou v podniku nasazeny. Nabídnutými prvky byly: internet věcí, cloud, kyber-fyzické systémy, Big Data Analytics, umělá inteligence, 3D tiskárny a virtuální dvojče. Ke každému z těchto prvků měl respondent zaškrtnout odpověd', zda je prvek: využíván pro účely údržby, využíván v podniku a do údržby nasazován, v podniku využíván, do podniku nasazován, zda prvek teprve plánují nasadit, případně že netuší, o co jde. $\checkmark$ prípadě, že nezaškrtl ani jednu z těchto odpovědí, mủžeme z toho vyvozovat, že daný prvek neřeší, či o jeho zapojení do podniku zatím neuvažují.

Podíváme-li se na míru zapojení, musíme konstatovat, že jednoznačně nejčastěji prvky nejspíše neřeší či že je teprve plánují nasadit do podniku. Z dotazníku vyplynulo, že pouze jeden podnik využívá pro údržbu dva $z$ uvedených prvků, a to sice Big Data Analytics a 3D tisk. Tento podnik zároveň odpověděl, že větší část prvků již v podniku využívají. [9] 
Tabulka 2 - Odpovědi na otázku ,jaké z následujících prvků Průmyslu 4.0 využíváte?

\begin{tabular}{|c|c|c|c|c|c|c|c|}
\hline \multicolumn{8}{|c|}{ Jaké z následujících prvků Průmyslu 4.0 využíváte? } \\
\hline $\begin{array}{c}\text { Jakým } \\
\text { způsobem } \\
\text { jsou již prvky } \\
\text { zapojeny }\end{array}$ & $\begin{array}{l}\text { Internet } \\
\text { věcí (loT) }\end{array}$ & Cloud & $\begin{array}{l}\text { Kyber- } \\
\text { Fyzické } \\
\text { systémy } \\
\text { (CPS) }\end{array}$ & $\begin{array}{l}\text { Big Data } \\
\text { Analytics }\end{array}$ & $\begin{array}{l}\text { Umělou } \\
\text { inteligenci } \\
\text { (Al) }\end{array}$ & $\begin{array}{l}\text { 3D } \\
\text { tiskárnu }\end{array}$ & $\begin{array}{l}\text { Virtuální } \\
\text { dvojče }\end{array}$ \\
\hline $\begin{array}{l}\text { Využíváme } \\
\text { pro účely } \\
\text { údržby }\end{array}$ & 0 & 0 & 0 & 1 & 0 & 1 & 0 \\
\hline $\begin{array}{l}\text { V podniku } \\
\text { využíváme, } \\
\text { nasazujeme } \\
\text { do údržby }\end{array}$ & 2 & 1 & 0 & 0 & 1 & 0 & 1 \\
\hline $\begin{array}{l}\text { V podniku } \\
\text { využíváme }\end{array}$ & 1 & 2 & 1 & 2 & 1 & 2 & 0 \\
\hline $\begin{array}{l}\mathrm{V} \text { podniku } \\
\text { nasazujeme }\end{array}$ & 1 & 1 & 1 & 1 & 0 & 1 & 0 \\
\hline $\begin{array}{l}\text { Plánujeme } \\
\text { nasadit v } \\
\text { podniku }\end{array}$ & 4 & 2 & 0 & 3 & 3 & 2 & 2 \\
\hline $\begin{array}{c}\text { Nevíme, o co } \\
\text { jde }\end{array}$ & 0 & 0 & 3 & 1 & 1 & 0 & 3 \\
\hline $\begin{array}{l}\text { Neřešíme/ o } \\
\text { jeho použití } \\
\text { neuvažujeme }\end{array}$ & 3 & 5 & 6 & 3 & 5 & 5 & 5 \\
\hline
\end{tabular}

\subsection{Napojení zařízení $\mathbf{k}$ internetu a jejich monitorování}

Napojení strojů a zařízení se v jednotlivých podnicích velmi liší. Lze však konstatovat, že u $63 \%$ podniků je zapojeno a monitorováno méně jak $50 \%$ zařízení. U čtyř podniků pak odhadují napojení 50-70 \%. 


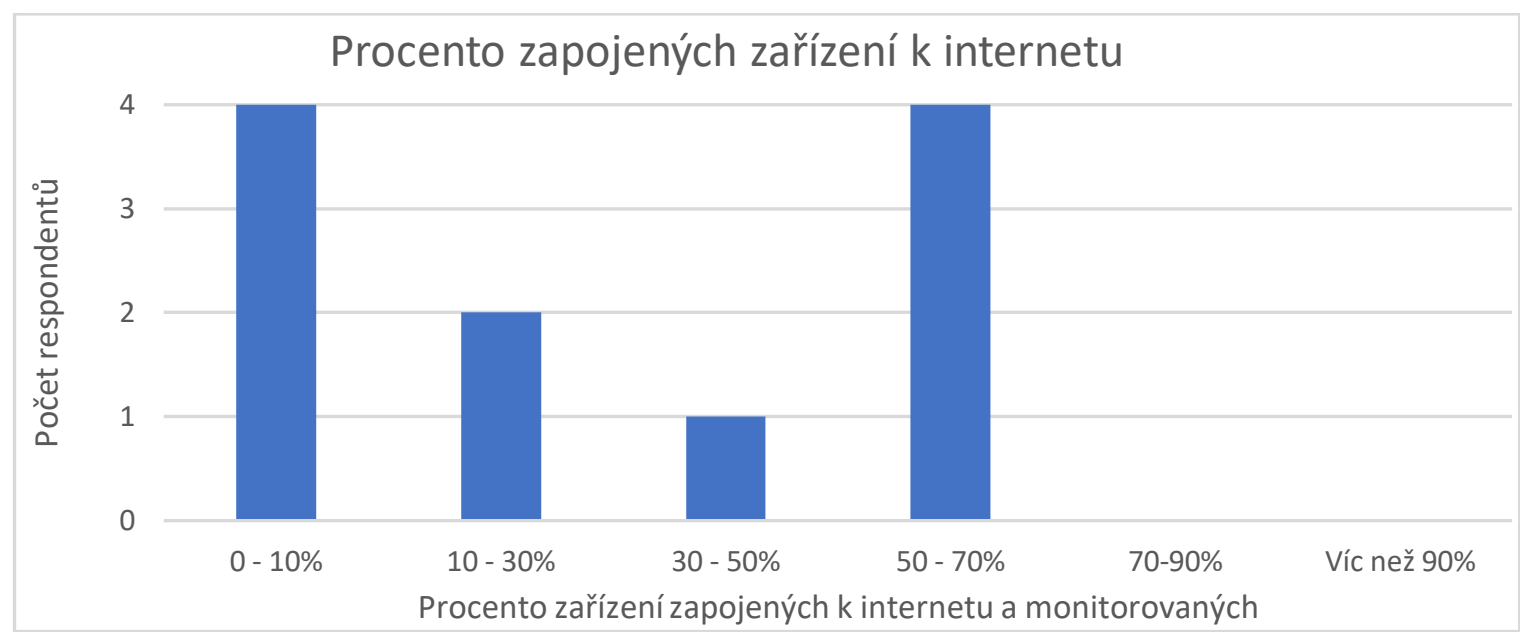

Graf 1 - Odpovědi na otázku „Kolik procent zařízení je pripojeno k internetu a monitorováné?"

Na otázku, jakým způsobem jsou zařízení monitorována, odpověděly podniky nejčastěji $(64 \%)$, že pomocí nástrojů a real-time monitoringu. Pouze jeden podnik uvedl, že využívají prediktivních technik.

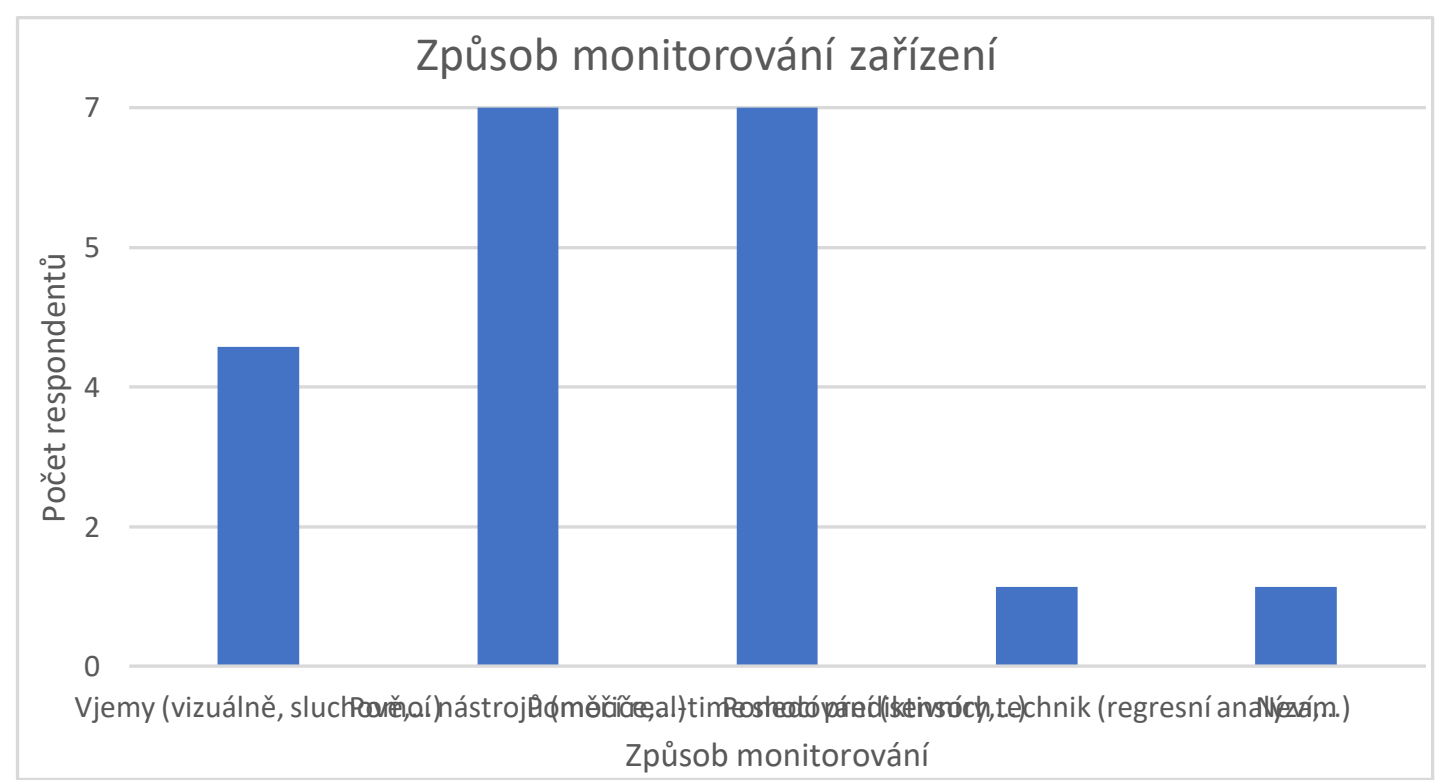

Graf 2 - Odpovědi na otázku „Jakým způsobem jsou Vaše zařizení monitorována?“

\section{3 Údržbářský tým}

$\mathrm{Na}$ otázku, jaké specialisty podniky $v$ údržbářském týmu zaměstnávají, odpovědělo pět podniků $z$ jedenácti, že zaměstnává $v$ údržbě i jiné pozice než techniky. Nejčastěji, čtyřikrát, zaměstnávali IT specialisty. 


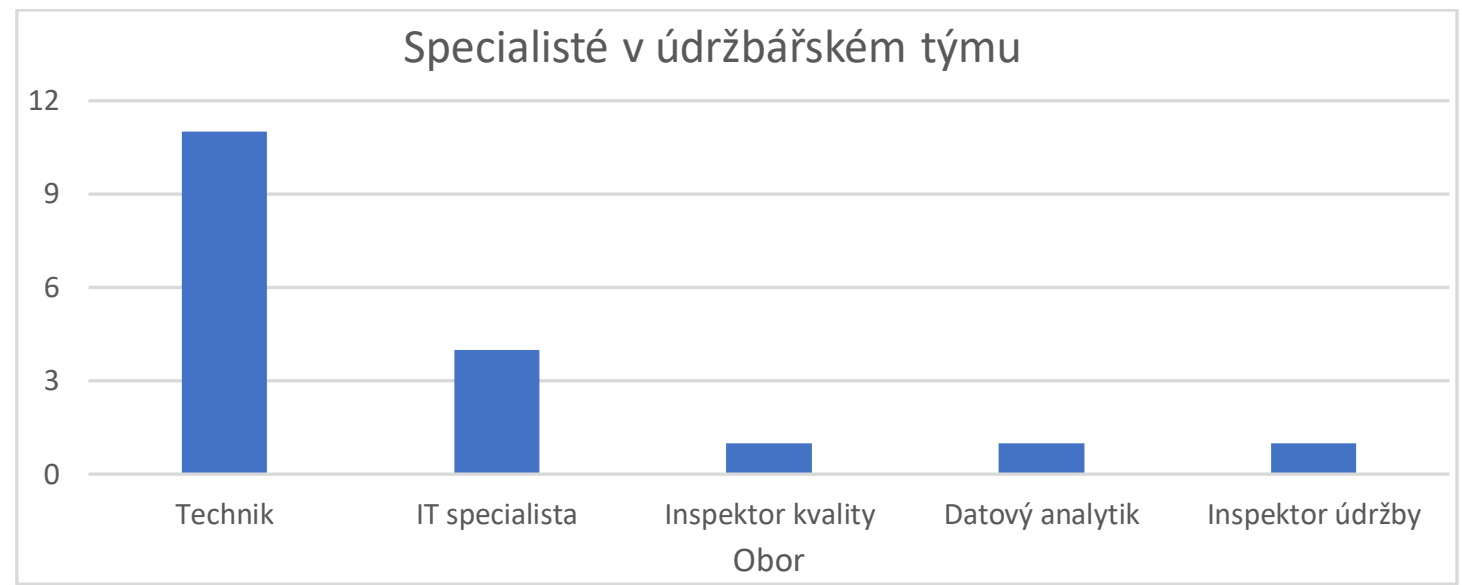

Graf 3 - Odpovědi na otázku „Jaké specialisty v údržbářském týmu zaměstnáváte?“

\subsection{Celková efektivita zařizení (OEE) klíčových zařízení}

Na dotaz, jaká je celková efektivita zařízení (OEE) na klíčových zařízeních, odpovědělo $55 \%$ respondentů, že OEE sleduje, $36 \%$ že OEE nesleduje a $9 \%$ neodpovědělo. Nejčastěji respondenti uvedli, že se OEE na klíčových zařízeních pohybuje na více jak 90 procentech.

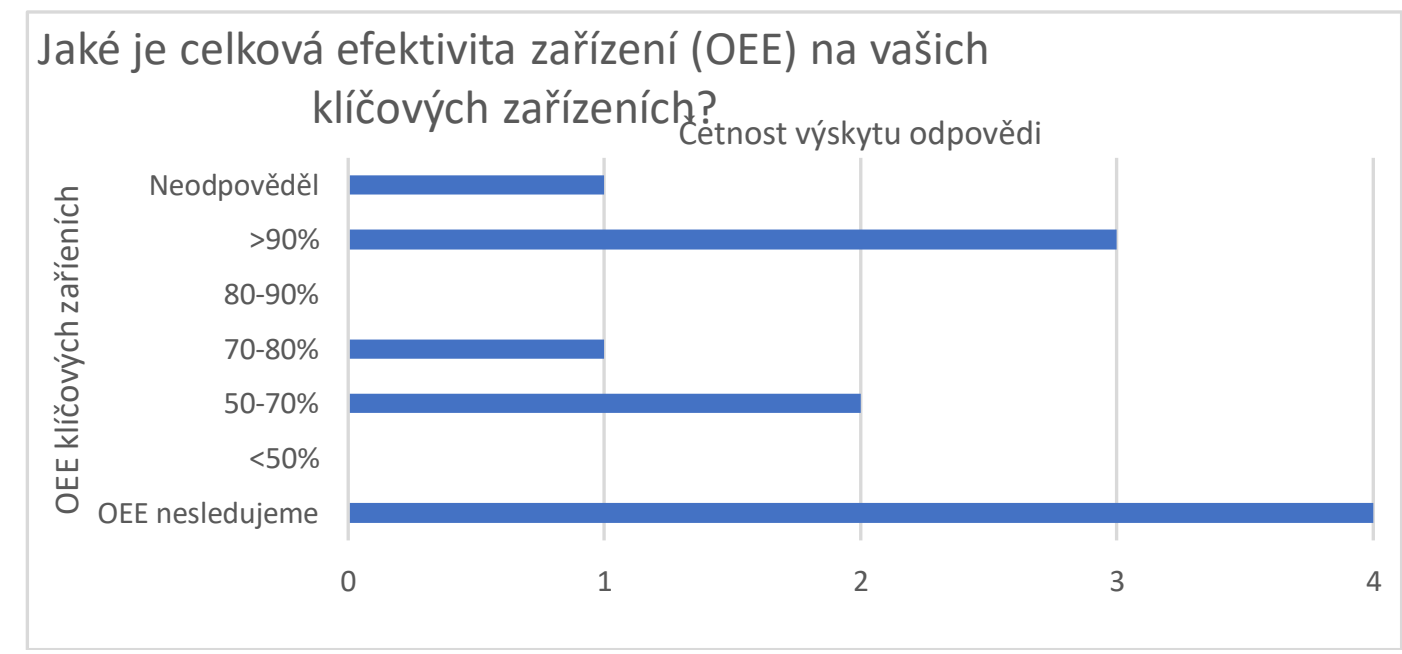

Graf 4 - Odpovědi na otázku „Jaká je celková efektivita zařizení (OEE) na Vašich klíčových zarízzeních?"

\section{Závěr}

V první části tohoto článku byly probrány charakteristiky průmyslových revolucí a s nimi se vyvíjejícím prístupem k rízení údržby. V druhé části pak byly publikovány výsledky dotazníku.

Porovnáme-li výsledky dotazníku s maticí řízení údržby $v$ kontextu průmyslových revolucí, můžeme konstatovat, že údržba v podnicích teprve začíná využívat prvků čtvrté průmyslové revoluce. Z prvků čtvrté průmyslové 
revoluce, využívají podniky především real-time monitoring za pomoci sensorů a připojení $k$ internetu. Predikce je zatím ojedinělá. Údržbářský tým nejčastěji zahrnuje techniky a IT specialisty, nikoliv však datové specialisty. Výše OEE často není sledována a pouze u 36 \% respondentů byla vyšší jak $90 \%$.

Přestože získaných odpovědí nebylo mnoho, Ize na jejich základě konstatovat, že úroveň údržby je svou úrovní spíše na úrovni prvků charakteristických pro třetí průmyslovou revoluci.

\section{Poděkování}

Tento článek byl vytvořen za podpory interního grantu Západočeské univerzity číslo SGS-2018-031 s názvem Optimalizace parametrư udržitelného výrobního systému.

\section{Použitá literatura}

[1] Coleman, Ch., Damodaran, S., Chandramouli, M., Deuel, E. Making maintenance smarter-Predictive maintenance and the digital supply network [online], May 09, 2017, Deloitte University Press [cit. 2019-08-12]. Dostupné z: https://www2.deloitte.com/insights/us/en/focus/industry-4-0/usingpredictivetechnologies-for-asset-maintenance.html

[2] Brugsch-Bey, H. A History of Egypt under the Pharaohs. Edited by Philip Smith, London, 1881.

[3] API STD 689. Collection and Exchange of Reliability and Maintenance Data for Equipment. First Edition, July 2007.

[4] Spear, B., Watt, J. The steam engine and the commercialization of patents. In: World patent information, 2008, vol. 30, no. 1, p. 53-58.

[5] Henderson, W., O. Industrial Revolution on the Continent: Germany, France, Russia 1800-1914. CRC Press, Routledge, 2013. ISBN 9781138879805.

[6] Ford Motor Company. Ford Manual for Owners and Operators of Ford Cars and Trucks. Detroit: Ford Motor Company, 1919.

[7] Jensen, M., C. The modern industrial revolution, exit, and the failure of internal control systems. In: The Journal of Finance, 1993, vol. 48, no. 3, p. 831-880.

[8] Legát a kol. Systémy managementu jakosti a spolehlivosti v údržbě. Praha : Česká společnost pro jakost, 2007, ISBN 978-80-02-01949-7.

[9] Poor, P., Zenisek, D., Basl, J. Historical Overview of Maintenance Management Strategies: Development from Breakdown Maintenance to Predictive Maintenance in Accordance with Four Industrial Revolutions. preprint, 2019. 